НАУКОВИЙ ВІСНИК

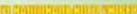

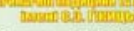

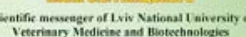

$\rightarrow$

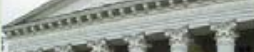

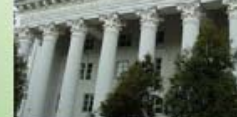
Toм 21 Nig 90

2019
Науковий вісник Дьвівського національного університету ветеринарної медицини та біотехнологій імені С.3. Гжицького. Серія: Сільськогосподарські науки

\author{
Scientific Messenger of Lviv National University
} of Veterinary Medicine and Biotechnologies.

Series: Agricultural sciences

UDC 636.2.088.636.084

\title{
Hematological indices of cows and their milk production for use in the composition of the diet of the drug "Biosprint"
}

\author{
B.S. Denkovich, M.V. Kharko, Y.I. Pivtorak
}

Stepan Gzhytskyi National University of Veterinary Medicine and Biotechnologies Lviv, Ukraine

Article info

Received 28.01.2019

Received in revised form 01.03 .2019

Accepted 04.03.2019

Stepan Gzhytskyi National University of Veterinary Medicine and Biotechnologies Lviv, Pekarska Str., 50, Lviv, 79010, Ukraine.

Tel.: +38-050-522-86-23 E-mail: yaroslavpivtorak@gmail.com
Denkovich, B.S., Kharko, M.V., \& Pivtorak, Y.I. (2019). Hematological indices of cows and their milk production for use in the composition of the diet of the drug "Biosprint". Scientific Messenger of Lviv National University of Veterinary Medicine and Biotechnologies. Series: Agricultural sciences, 21(90), 32-36. doi: 10.32718/nvlvet-a9006

In the conditions of intensive milk production, to ensure high productivity and at the same time preserve the health of animals, it is impossible to avoid the use of feeding probiotic supplements. In particular, there is a resurgence of interest in the use of live yeast cultures based on Saccharomyces cerevisiae. One of these is the microbial supplement "Biosprint", which contains live yeast cultures (Saccharomyces cerevisiae, MUCL strain 39885), and is a probiotic supplement for high-yield dairy cows. High milk productivity requires constant monitoring of the state of metabolism, animal health, early diagnosis and timely medical and prophylactic measures. The whole process of metabolism between the cells of the body and the environment occurs through the blood that transports nutrients to the cells, removing from them the products of their metabolism. This explains the relevance of studying the biochemical parameters of blood serum, which are important for assessing the level of metabolism in the body of animals. which directly affects their productivity. The purpose of our research was to study the biochemical parameters of blood when the "Biosprint" drug was added to the diet. The research was carried out on animals of the Simmental breed under the conditions of the farm "Pchani-Denkovich", Zhydachiv district, Lviv region. The basis of research is the task of optimization of normalized feeding of high-yielding dairy cows due to the use of the composition of the dietary supplement "Biosprint", to establish its influence on the state of metabolism in animals based on the analysis of indicators of morphological and biochemical composition of blood, as well as milk production, and to do conclusion on the optimal amount of ii and the introduction of the composition of concentrated diet rations.

Key words: rations, probiotic supplements, nutritional supplements, metabolism, biochemical and morphological parameters of blood, milk production, protein components, resistance.

\section{Гематологічні показники корів та їх молочна продуктивність використання у складі раціону препарату "Biosprint"}

\author{
Б.С. Денькович, М.В. Харко, Я.І. Півторак
}

Львівський національний університет ветеринарної медицини та біотехнологій імені С.3. Гжсиького м. Львів, Украӥна

В умовах інтенсивного виробництва молока, щоб забезпечити високу продуктивність і при тому зберегти здоров'я тварин, неможливо обійтись без застосування в годівлі пробіотичних добавок. Зокрема, спостерігається відродження зацікавленості до використання живих дріжджових культур на основі Saccharomyсеs cerevisiae. До однієї із таких відноситься мікробіальна добавка "Biosprint”, яка містить живі дріжджсві культури (Saccharomyсеs сеrevisiae, штам MUCL, 39885) i є пробіотичною добавкою для високопродуктивних молочних корів. Висока молочна продуктивність потребує постійного моніторингу за станом обміну речовин, здоров'ям тварин, ранньою діагностикою і своєчасним проведенням лікувально-профілактичних заходів. Весь процес обміну речовин між клітинами організму та зовнішнім середовищем відбувається через кров, яка транспортує поживні речовини 
до клітин, забираючи від них продукти їх метаболізму. Це пояснює актуальність вивчення біохімічних показників сироватки крові, які мають важливе значення для очінки рівня обміну речовин в організмі тварин, який безпосередньо впливає на їхню продуктивність. Метою наших досліджень було вивчення біохімічних показників крові при включенні в рачіон препарату “Віолргіпt”. Дослідження проводили на тваринах симентальської породи в умовах фермерського господарства “Пчани-Денькович” Жидачівського району Львівської області. В основу проведення досліджень покладено завдання оптимізацї нормованої годівлі високопродуктивних дійних корів за рахунок використання в складі раціону кормової добавки “Віоsргіпt”, встановити ї̈ вплив на стан обміну речовин у тварин на основі аналізу показників морфологічного та біохімічного складу крові, а також молочну продуктивність та зробити висновок щчодо оптимальної кількості ї̈ введення до складу концентрованих кормів раціону.

Ключові слова: рачіони, пробіотичні добавки, кормодобавка, обмін речовин, біохімічні та морфологічні показники крові, молочна продуктивність, білкові компоненти, резистентність.

\section{Вступ}

В умовах інтенсивного виробництва молока, щоб забезпечити високу продуктивність корів і при цьому зберегти здоров'я тварин, неможливо обійтися без застосування в годівлі дійних корів пробіотичних добавок. Зокрема, в останні роки особливо спостерігається відродження зацікавленості до використання пробіотичних кормових добавок на основі Saccharomyces cerevisiae. До однієї із таких відноситься мікробіальна добавка "Biosprint", яка містить живі дріжджові культури (Saccharomyces cerevisiae, штам MUCL, 39885) і виконує пробіотичні функції в шлунково-кишковому тракті тварин на противагу антибіотикам, заборона на використання яких підвищила вимоги до пробіотиків, їхньої дії на екосистему травного тракту, обмін речовин та загальну продуктивність лактуючих корів, особливо на якісні показники молока. Встановлено, що пробіотичні властивості дріжджових культур проявляються в здатності виживати в травному тракті завдяки використання кисню, який потрапляє у рубець 3 кормами та впливати антагоністично на патогенні мікроорганізми, такі як Esherichia coli, Shigella та Salmonella. Дріжджові культури безпечні, стійкі до антибіотиків, досягають високої концентрації у кишечнику і за короткий проміжок часу колонізують його, а також швидко очищуються після припинення введення.

Одним 3 найбільш значних повідомлень про дію живих дріжджових добавок на збільшення кількості й активність бактеріальної маси в рубці жуйних і особливо високопродуктивних корів спостерігається на раціонах з високим вмістом концентратів (LourensHattingh \& Viljoen, 2001; McFarland, 2007).

Багаторічний досвід застосування живих дріжджів і праці багатьох вчених з різних країн світу підтверджують їх позитивний вплив на мікрофлору рубця i як наслідок - підвищення продуктивності та зміцнення здоров'я тварин. Проте результати досліджень часто відрізняються й інколи є навіть суперечливими. Ці відмінності можуть залежати від багатьох факторів, таких як умови навколишнього середовища, стадії лактації, типу годівлі корів, структури раціону, дозування дріжджів, техніки згодовування. Це обумовлює необхідність перевіряти продуктивну дію живих дріжджів на організм тварин в конкретних умовах тваринницьких підприємств.

Висока молочна продуктивність потребує постійного моніторингу за станом обміну речовин, здоров'ям тварин, ранньою діагностикою і своєчасним проведенням лікувально-профілактичних заходів (LeBlanc, 2010). Одним з основних показників фізіологічного стану тварин і їхньої продуктивності є дані, що отримані при дослідженні крові, оскільки зрушення метаболічних процесів знаходить адекватне відображення у змінах складу крові як внутрішнього середовища організму.

Відомо про ізотонічну рівновагу між кров'ю та молоком, проте такої рівноваги між окремими компонентами крові та молока не було виявлено. Клітини молочних залоз використовують до $80 \%$ доступних поживних речовин для синтезу молока 3 крові. Основними попередниками молочних складових $є$ вільні амінокислоти, глюкоза, ацетат, жирні кислоти та триацилгліцероли, 3 яких утворюються молочні білки, лактоза та молочний жир. Обмеження будь-якого 3 них зменшує синтез молока та змінює його склад (LeBlanc, 2010).

Таким чином, весь процес обміну речовин між клітинами організму та зовнішнім середовищем відбувається через кров, яка транспортує поживні речовини до клітин, забираючи від них продукти їхнього метаболізму. Це пояснює актуальність вивчення впливу мікробних пробіотичних добавок на біохімічні показники сироватки крові корів, які мають важливе значення для оцінки рівня обміну речовин в організмі тварин, що безпосередньо впливає на їх продуктивність.

\section{Матеріал і методи досліджень}

Дослідження проводились у фермерському господарстві "Пчани-Денькович" Жидачівського району Львівської області на чотирьох групах корів симентальської породи по десять голів у кожній групі за схемою, наведеною у таблиці 1. Тривалість досліду 90 діб. 
Таблиця 1

Схема проведення науково-виробничого досліду

\begin{tabular}{ccl}
\hline Групи & Кількість, гол & \multicolumn{1}{c}{ Особливості годівлі тварин } \\
\hline Контрольна & 10 & Основний раціон (ОР) - скошена зелена трава люцерни $-70 \%$, сіно злаково \\
1. дослідна & 10 & бобове $-9,5 \%$, концентрати $-20 \%$, премікс $-0,5 \%$. \\
2. дослідна & 10 & OP + "Biosprint" -4 г гол/добу \\
3. дослідна & 10 & OP + “Biosprint" -5 г гол/добу \\
\hline
\end{tabular}

Проби молока були взяті при кожному доїнні протягом останніх 2 суміжних днів дослідного періоду. Кількість молока, вміст жиру, білків, лактози та кількості соматичних клітин визначали на основі контрольного доїння та аналізу молока. Вміст жиру, білка та лактози визначали за допомогою Milkoscan та кількості соматичних клітин - Fossomatic.

Зразки крові відбирали з яремної вени 5 тварин 3 кожної групи в останній день кожного місяця, приблизно через 4 години після ранкової годівлі. Дослідження зразків крові здійснювали за методиками, описаними В.В. Влізлом (Vlizlo et al., 2012) ита И.П. Кондрахиним (Kondrakhin, 2004). Стан обміну речовин у тварин визначали за такими показниками: загальний білок, білковий профіль (альбумін, глобуліни), концентрацію сечовини, глюкози, вміст креатиніну, активність аспартатамінотрансферази (АсАТ) та амінотрансферази (АлАТ), загальний холестерин, кислотна ємність. Крім того, у сироватці крові визначали рівень вітамінів А та Е, кальцій та фосфор - за загальноприйнятими методиками.

Статистичну обробку матеріалів досліджень здійснювали загальноприйнятими методами варіаційної статистики $з$ оцінкою (M), його похибки (m) і розрахунками вірогідності різниць за методом Стюдента 3 використанням програмного забезпечення "Microsoft Excel 2003".

\section{Результати та їх обговорення}

Дослідження метаболітів крові з метою контролю стану здоров'я лактуючих корів залежно від впливу досліджуваного фактора наведені у таблиці 2. Порів- няльний аналіз між гематологічними показниками показав зростання вмісту гемоглобіну та еритроцитів на 3,8-4,8\% порівняно 3 контролем. Що стосується лейкоцитів, їх вміст перебував практично на однаковому рівні. Проте, за фагоцитарною активністю нейтрофілів у крові тварин дослідних груп спостерігається ïx зростання на 6,4\% - у другій групі 6,5\% - в третій, що вказує на позитивну дію препарату "Biosprint".

Біохімічний профіль показників сироватки крові корів при включенні в раціон препарату "Biosprint" наведений в таблиці 3.

Білки крові є будівельним матеріалом для клітин і тканин самого організму, а також беруть активну участь в утворенні молочної продукції. Рівень основних білків крові альбумінів і глобулінів характеризує забезпеченість тварин білками корму. Аналізуючи білковий обмін, ми виявили що кількість загального білка і його фракцій в крові тварин були в межах фізіологічної норми. Дещо вищий показник вмісту альбумінів спостерігався у тварин 2-ї та 3-ї дослідних груп. Рівень загального білка в сироватці крові тварин контрольної групи був дещо нижчим порівняно із тваринами дослідних груп, аналогічна тенденція прослідковується за вмістом глобулінів. Підвищення рівня глобулінів у сироватці крові корів дослідних груп може свідчити про збільшення резистентності організму.

Кінцевими продуктом білкового обміну є сечовина, яка відображає концентрацію аміаку в рубці жуйних тварин, а іiї вміст в крові та молоці впливає не тільки на споживання сирого протеїну, а і його перетравлюваність, а також баланс енергії в організмі тварин.

Таблиця 2

Морфологічні компоненти крові корів ( $\mathrm{M} \pm \mathrm{m}, \mathrm{n}=5)$

\begin{tabular}{|c|c|c|c|c|}
\hline \multirow{3}{*}{ Показник } & \multicolumn{4}{|c|}{ Групи тварин } \\
\hline & \multirow{2}{*}{ Контрольна } & \multicolumn{3}{|c|}{ Дослідні } \\
\hline & & 1 & 2 & 3 \\
\hline Гемоглобін, г/л & $101,7 \pm 3,41$ & $103,5 \pm 1.72$ & $104,9 \pm 2,86$ & $105,7 \pm 2,73^{*}$ \\
\hline Еритроцити, млн/мкл ${ }^{3}$ & $6,63 \pm 0,29$ & $6,82 \pm 0,13$ & $6,90 \pm 0,34$ & $6,96 \pm 0,25^{*}$ \\
\hline Лейкоцити, тис/мм ${ }^{3}$ & $7,92 \pm 0,39$ & $7,93 \pm 0,35$ & $7,94 \pm 0.32$ & $7,94 \pm 0,45$ \\
\hline Фагоцитарна активність, \% & $39,1 \pm 2,20$ & $41,3 \pm 1,87$ & $45,7 \pm 2,67$ & $4,58 \pm 2,75$ \\
\hline
\end{tabular}

Примітка: *P <0,05, **P <0,01

Зміна рівня сечовини в крові пов'язана насамперед 3 функціональним станом печінки. Велика частина протеїну кормів піддається в рубці гідролізу до амінокислот 3 подальшим їх дезамінуванням до аміаку, надлишок якого всмоктується в кров, потрапляє в печінку і перетворюється в сечовину, що в кінцевому підсумку, приводить до їі зростання в організмі.
В наших дослідженнях спостерігається збільшення концентрації сечовини в крові корів, у раціон яких вводили препарат "Biosprint" (друга і третя дослідні групи).

Відомо, що ферменти крові є біологічними каталізаторами, які беруть участь у всіх життєво-важливих процесах організму і за якими також можна судити 
про перебіг обмінних процесів в організмі, та враховуючи те, що в синтезі білка найбільше значення мають ферменти, які каталізують перетворення, у яких бере участь глутамінова кислота, так звані трансамі- нази крові, нами була проаналізована активність аспартат-амінотрансфераз (АсАТ) та аланінамінотрансфераз (АлАТ).

Таблиця 3

Біохімічний профіль показників сироватки крові корів $(\mathrm{M} \pm \mathrm{m}, \mathrm{n}=5)$

\begin{tabular}{|c|c|c|c|c|}
\hline \multirow{3}{*}{ Показник } & \multicolumn{4}{|c|}{ Групи тварин } \\
\hline & \multirow{2}{*}{ Контрольна } & \multicolumn{3}{|c|}{ Дослідні } \\
\hline & & 1 & 2 & 3 \\
\hline Загальний білок, г/л & $81,83 \pm 1,76$ & $81,34 \pm 1,44$ & $84,16 \pm 1,29$ & $85,2 \pm 0,48^{*}$ \\
\hline Альбуміни, г/л & $34,14 \pm 2,80$ & $35,7 \pm 1,62$ & $37,04 \pm 0,56$ & $38,3 \pm 0,49^{*}$ \\
\hline Глобуліни, г/л & $47,69 \pm 2,49$ & $45,64 \pm 0,90$ & $47,12 \pm 4,4$ & $46,9 \pm 0,72$ \\
\hline$\alpha$-глобуліни, г/л & $12^{\prime}, 96 \pm 0,70$ & $12,78 \pm 0,25$ & $13,19 \pm 0,35$ & $13,13 \pm 0,20$ \\
\hline$\beta$ - глобуліни, г/л & $13,4 \pm 0,65$ & $10,95 \pm 0,22$ & $11,31 \pm 0,30$ & $11,26 \pm 0,17$ \\
\hline$\gamma$-глобуліни, г/л & $21,33 \pm 1,20$ & $21,91 \pm 0,43$ & $22,62 \pm 0,60$ & $22,51 \pm 0,35$ \\
\hline Білковий коефіцієнт, Аi & $0,79 \pm 0,10$ & $0,78 \pm 0,02$ & $0,79 \pm 0,03$ & $0,81 \pm 0,02$ \\
\hline АсАТ, од/л & $47 \pm 1,77$ & $45 \pm 1,58$ & $41 \pm 2,09$ & $39 \pm 1,70$ \\
\hline АлАТ, од/л & $23 \pm 1,40$ & $20 \pm 1,84$ & $18 \pm 2,15$ & $16 \pm 2,37$ \\
\hline Глюкоза, ммоль/л & $2,56 \pm 0,07$ & $2,77 \pm 0,08$ & $2,9 \pm 0,05$ & $2,94 \pm 0,05$ \\
\hline Сечовина, ммоль/л & $3,62 \pm 0,09$ & $3,78 \pm 0,12$ & $3,93 \pm 0,18$ & $4,05 \pm 0,18$ \\
\hline Каротин, мг\% & 0,51 & 0,52 & 0,52 & 0,54 \\
\hline Холестерин, ммоль/л & $3,53 \pm 0,157$ & $3,40 \pm 0,163$ & 3,42 & 3,51 \\
\hline Кальцій загальний, ммоль л & $2,61 \pm 0,10$ & $2,68 \pm 0,93$ & $2,74 \pm 0,76$ & $2,81 \pm 0,06^{*}$ \\
\hline Фосфор неорганічний, ммоль/л & $1,59 \pm 0,04$ & $1,62 \pm 0,32$ & $1,66 \pm 0,06$ & $1,68 \pm 0,07 *$ \\
\hline
\end{tabular}

Примітка: *P $<0,05, * * \mathrm{P}<0,01$

Виявлено, що згодовування в структурі раціону препарату "Biosprint" в кількості 4-5 г/гол./добу сприяє зниженню активності АлАТ. Аланінамінотрансфераза - це тканинний фермент, каталітична активність якого підвищується при нестачі глюкози з метою її синтезу з амінокислот. Оскільки у крові тварин зазначених груп спостерігається підвищення вмісту глюкози та загального білка в крові, це призводить до зменшення використання ферментів. Зниження активності трансаміназ у сироватці крові може свідчити про зменшення інтенсивності деструктивних процесів в печінці (Stojevic et.al., 2005). Зміна рівня цукру в крові корів обернено-пропорційно впливає на активність аланін-амінотрансферази (Sakowski et al., 2012).

Одним з основних біохімічних показників, що характеризують вуглеводний обмін, є рівень глюкози в крові. Вуглеводний обмін відповідає за забезпеченість організму енергією. На рівень вуглеводного обміну у тварин, крім вуглеводної забезпеченості раціону, впливає активність бродильних процесів в передшлунках, оскільки основна частина вуглеводів у них використовується у вигляді летких жирних кислот, які беруть участь в синтезі глікогену, жиру і в енергетичному обміні.

У тварин дослідних груп при додаванні препарату "Biosprint" спостерігалося збільшення концентрації глюкози в сироватці крові порівняно з контрольною групою.

Про збільшення концентрації глюкози в сироватці крові, коли при теплових стресах у раціони молочних корів вводили живі дріжджі повідомляли DehgnanBanadaky et a1., та Yalcin S. et.al. (Yalcin et al., 2011;
Dehgnan-Banadaky et a1., 2013). Для характеристики жирового обміну визначали рівень холестерину в крові, вміст якого в крові корів перебуває в прямій кореляції 3 молочною продуктивністю тварин (Gromyko, 2005). Холестерин також є попередником стероїдних гормонів. Особливих змін концентрації холестерину в крові тварин при включенні в раціон препарату “Biosprint” нами не виявлено.

Швидкість ферментних реакцій залежить і від концентрація макро- та мікроелементів. Зокрема особливу увагу приділяють кальцію і фосфору. Зростання вмісту неорганічного фосфору у крові за умов наших досліджень свідчить про порівняно вищу активність обміну речовин у кістковій тканині, що можна визнати позитивним.

Кров і молоко нерозривно пов'язані між собою оскільки клітини молочних залоз використовують до $80 \%$ доступних поживних речовин для синтезу молока 3 крові. Отримані результати досліджень дають підставу стверджувати про наявність прямого зв'язку між показниками крові та рівнем молочної продуктивності корів (табл. 4).

Важливо при цьому підкреслити, що введення в структуру раціону піддослідних корів препарату пробіотичної дії “Biosprint” забезпечило зростання рівня середньодобового надою молока на 1 голову стосовно контрольної групи на 1,4-2,5 кг, або 4,4-7,8\%, а у перерахунку на базисну жирність цей показник становить 6,5-10,5\%. Відзначено також підвищення рівня СЗМ3 на 2,8-3,4\%, а також тенденцію до зростання вмісту жиру на $0,08-0,10 \%$, загального білка на 0,10 $0,11 \%$, і як наслідок - густини молока корів дослідних груп, що вказує на поліпшення його якості. 
Таблиця 4

Молочна продуктивність піддослідних корів $(\mathrm{M} \pm \mathrm{m}, \mathrm{n}=10)$

\begin{tabular}{|c|c|c|c|c|}
\hline \multirow{3}{*}{ Показники } & \multicolumn{4}{|c|}{ Групи корів } \\
\hline & \multirow{2}{*}{ Контрольна } & \multicolumn{3}{|c|}{ Дослідні } \\
\hline & & 1 & 2 & 3 \\
\hline $\begin{array}{c}\text { Середньодобовий надій молока: } \\
-\quad \text { натуральної жирності, кг }\end{array}$ & $31,8 \pm 0,63$ & $33,2 \pm 0,48$ & $33,9 \pm 0,21$ & $34,3 \pm 0,19$ \\
\hline - базисної жирності , кг & $35,1 \pm 0,49$ & $37,4 \pm 0,51$ & $38,4 \pm 0,48$ & $38,8 \pm 0,51$ \\
\hline $\begin{array}{l}\text { Вміст в молоці, \%: } \\
\text { - } \quad \text { жиру }\end{array}$ & $3,75 \pm 0,06$ & $3,83 \pm 0,07$ & $3,84 \pm 0,05$ & $3,85 \pm 0,05^{*}$ \\
\hline - білка & $3,32 \pm 0,09$ & $3,42 \pm 0,09$ & $3,42 \pm 0,08$ & $3,43 \pm 0,09^{*}$ \\
\hline - лактози & $4,95 \pm 0,07$ & $5,02 \pm 0,06$ & $5,02 \pm 0,07$ & $5,03 \pm 0,07$ \\
\hline $\begin{array}{l}\text { СЗМЗ - сухий знежирений молоч- } \\
\text { ний залишок }\end{array}$ & $10,14 \pm 0,17$ & $10,43 \pm 0,20$ & $10,48 \pm 0,21$ & $10,49 \pm 0,18$ \\
\hline Соматичні клітини, тис в $1 \mathrm{~cm}^{3}$ & $200,2 \pm 17,21$ & $168,8 \pm 16,19$ & $150,3 \pm 17,33$ & $149,5 \pm 12,88^{*}$ \\
\hline Сечовина, мг/100 мл & $15,8 \pm 0,43$ & $17,1 \pm 0,55$ & $19,2 \pm 0,77$ & $19,5 \pm 0,67^{*}$ \\
\hline
\end{tabular}

Примітка: *P $<0,05, * * \mathrm{P}<0,01$

У тварин дослідних груп спостерігається підвищення вмісту лактози в молоці на 0,07-0,08\%. Кількість соматичних клітин в молоці у тварин всіх груп не перевищувала допустимих нормативів, проте менша їх кількість спостерігалась у тварин раціон, яких доповнювали препаратом "Biosprint”. Відмічено також зростання рівня сечовини в молоці дослідних тварин в межах допустимих норм, таке підвищення може бути результатом збільшення споживання засвоюваного сирого протеїну та метаболізмом енергії.

\section{Висновки}

Проведені дослідження за оцінкою впливу препаpaтy "Biosprint" на гематологічні показники корів, а також їх молочну продуктивність дають підставу твердити про доцільність його використання в структурі раціону літнього періоду в кількості 5-6 г/гол. добу.

Перспективи подальших досліджень будуть спрямовані на подальше вивчення впливу пробіотичних добавок типу "ПРОГАЛ" в годівлі лактуючих корів на фоні різної структури раціонів зимового та літнього періодів утримання.

\section{References}

Dehghan-Banadaky, M., Ebrahimi, M., Motameny, R., \& Heidaria, S.R. (2013). Effects of live yeast supplementation on mid-lactation dairy cows performances, milk composition, rumen digestion and plasma. Appl. Anim. Res., 41, 137-142. http://agris.fao.org/agrissearch/search.do?recordID=US201400122416.

Gromyko, Ye.V. (2005). Otsenka sostoyaniya organizma korov metodami biokhimii. Ekologicheskiy vestnik sevemogo Kavkaza, 2, 80-94 (in Russian).

Jelinek, P., Gajdoek, S., \& Illek, J. (1996). Relationship between selected indicators of milk and blood in sheep. Small Rum. Res., 20(1), 53-57. doi: 10.1016/0921-4488(95)00771-7.

Kharko, M.V., Denkovich, B.S., Pivtorak, Y.I., Naumyuk, A.S., Petryshak, R.A., Holodyuk, Y.P. (2017). Milk yield and metabolic processes in cows during the usage of the biosprint drug in the diet structure. Scientific Messenger LNUVMB, 19(79), 122-126. doi: 10.15421/nvlvet7924.

Kondrakhin, I.P. (2004). Metody veterinamoy klinicheskoy laboratomoy diagnostiki: spravochnik. M.: KolosS (in Ukrainian).

LeBlanc, S. (2010). Monitoring metabolic health of dairy cattle in the transition period. J. Reprod Dev, 56, 2935. https://www.ncbi.nlm.nih.gov/pubmed/20629214.

Lourens-Hattingh, A., \& Viljoen, B.C. (2001). Growth and survival of a probiotic yeast in dairy products. Food Res. Int, 34(9), 791-796. doi: 10.1016/S09639969(01)00085-0.

McFarland, L.V. (2007). Meta-analysis of probiotics for the prevention of traveler's diarrhea. Travel Med. Infect. Dis., 5(2), 97-105. doi: 10.1016/j.tmaid.2005.10.003.

Sakowski, T., Kuczynska, B., Puppel, K., Metera, E., Sloniewski, K., \& Barszczewski, J. (2012). Relationships between physiological indicators in blood, and their yield, as well as chemical composition of milk obtained from organic dairy cows. J Sci Food Agric, 92(14), 2905-2912. doi: 10.1002/jsfa.5900.

Stojevic, Z., Pirsljin, J., Milinkovic-Tur, S., Zdelar-Tuk, M., \& Beer Ljubic, B. (2005). Activities of AST, ALT and GGT in clinically healthy dairy cows during lactation and in the dry period. Veterinarski arhiv, 75(1), 67-73. https://hrcak.srce.hr/67059.

Turko, I.B. (1986). Transaminaznaya aktivnost' syvorotki krovi u korov pri razlichnom ikh fiziologicheskom sostoyanii i urovne molochnoy produktivnosti. Nauch.-tekhn. byul. Ukrainskogo Nil fiziologii i biokhimii s.- kh. zhivotnykh. L'vov, 8(3), 15-17 (in Russian).

Vlizlo, V.V., Fedoruk, R.S., \& Ratych, I.B. (2012). Laboratomi metody doslidzhen u biologiyi, tvarynnycztvi ta veterynamij medycyni: dovidnyk. Lviv, Spolom (in Ukrainian).

Yalcin, S., Can, P., Gurdal, A.O., Bagci, C., \& Eitan, O. (2011). The Nutritive Value of Live Yeast Culture (Saccharomyces cerevisiae) and Its Effect on Milk Yield, Milk Composition and Some Blood Parameters of Dairy Cows. Asian-Aust. J. Anim. Sci., 24(10), 1377-1385. doi: 10.5713/ajas.2011.11060. 